\title{
POSSIBLE FACTORS FOR FOOD SAFETY INFRACTION AND FRAUD CONTINUITY IN RESTAURANTS IN SAUDI ARABIA
}

\author{
ABDULLAH F. ALSAYEQH \\ College of Agriculture and Veterinary Medicine, Qassim University, 6622, Buraidah 51452, Saudi Arabia.
}

\section{ABSTRACT}

Received at: $29 / 6 / 2015$

Accepted: 28/7/2015
Preventable foodborne diseases present an important public health burden worldwide. Reported estimates indicate that the majority of investigated foodborne disease outbreaks originated at restaurants where food safety infractions were committed. In the Kingdom of Saudi Arabia (KSA), critical food safety infractions and fraud are repeatedly observed at inspected restaurants. In this paper, the factors that may lead to the continuity of these violations are discussed. Labor, inspectors, and regulatory factors are issues that need to be reconsidered to improve food safety in restaurants and in the KSA in general.

Key words: Food safety, Restaurant, Infraction, Fraud, Saudi Arabia

\section{INTRODUCTION}

Foodborne illnesses are preventable diseases that affect people globally and present a growing public health concern (WHO, 2007). The proportion of foodborne disease outbreaks in which restaurants are implicated is unclear. However, restaurants are considered to be a major source of outbreaks (Jones and Angulo, 2006). Studies that investigated foodborne disease outbreaks reported that the majority of these outbreaks have been traced to foodservice establishments (Bean and Griffin, 1990; CDC, 2006; CDC, 2005; Collins, 1997; Nsoesie et al., 2014 and Todd et al., 2007). It is estimated that up to $70 \%$ of foodborne diseases that occur in developed countries are linked to food prepared at foodservice establishments (Jacob and Powell, 2009; Lee, and Middleton, 2003 and Nsoesie et al., 2014). This percentage is a high proportion considering the advancements in food safety regulations and food inspection processes. In developing countries, food and water contamination results in an estimated 2.2 million deaths every year (WHO, 2005).

Consumers have become more concerned about food safety in foodservice operations. Their trust in the safety of restaurant-prepared food, which is becoming more fragile, is affected by media coverage, which generally focuses on the low standards practiced in restaurants (Bruhn, 1997; Worsfold and Worsfold, 2008). Additionally, this mistrust could be due to the estimation that the majority of known reported foodborne illnesses has been caused by mistakes made in commercial foodservice establishments (CDC, 2005).

Because the foodservice sector employs thousands or millions of people in a country (Lo and Jacobson,
2011), the potential for mistakes and outbreak incidences in this sector is significant (Todd et al., 2008). Food workers have been involved in foodborne disease outbreaks in different settings. Outbreaks in a restaurant (Todd et al., 2007), resort hotel (Birkhead et al., 1993), wedding (Friedman et al., 2005), hospital (Fone et al., 2001), nursing home (White et al., 1989), school (Michino, and Otsuki, 2000), daycare center (Gotz et al., 2002), cruise ship (Cramer et al., 2003), airplane (Burslem et al., 1990), and private home (Latham and Schable, 1982) are examples of settings where food workers or their actions have been identified as the risk factors that led to the outbreak. The variety of settings where attendants can be affected in large numbers indicates the importance of food workers' state/behaviors in incidences of foodborne disease outbreaks (Todd et al., 2007).

Observational studies by the Food and Drug Administration (FDA, 2009) were conducted to identify risk factors for foodborne illness in retail operations, schools, nursing homes, and restaurants. The lowest compliance scores were observed in restaurants, a trend that was maintained for more than a decade. The risk factors identified included poor personal hygiene, improper holding temperature/time, cross-contamination, inadequate cooking, and chemical control (FDA, 2009). The first three factors represent a continuing problem that requires attention in a foodservice establishment (Riyadh Province Municipality, 2014). Employee knowledge and motivation can limit the contribution of these factors toward a foodborne illness outbreak (Arendt and Sneed, 2008.).

The Kingdom of Saudi Arabia (KSA) is the largest country within the Gulf Cooperation Council 
countries in terms of size, population, and economy. (United States Department of Agriculture, 2013). While self-sufficiency was reached for fresh milk and table eggs, KSA imports more than $80 \%$ of its food needs. With an annual increase of more than $8 \%$ per year, the import value of KSA agri-food products alone was approximately $\$ 22$ billion in 2012 (United States Department of Agriculture. 2013). Of this amount, 52\% was consumer-oriented food products. Food retail sales increased from $\$ 4.35$ billion in 2007 to $\$ 33.5$ billion in 2013. By 2020, KSA's food imports are estimated to be more than $\$ 35$ billion annually (United States Department of Agriculture, 2013).

The Saudi Commission for Tourism and Antiquities estimates that there are 28410 foodservice establishments (of which $7.9 \%$ are cafés) (United States Department of Agriculture, 2013). The number might be higher because many newly operating businesses are not regularly added to databases. The estimated number of meals served at such establishments is 2.8 billion annually. Restaurants and cafés in KSA are the primary points for socializing and meeting friends because other options are limited.

Currently, the burden of foodborne diseases in KSA is not known. Because there is only one system surveying these diseases, which belongs to Ministry of Health $(\mathrm{MOH})$, estimates of foodborne disease incidence rates are only available for the diseases that require $\mathrm{MOH}$ notification (Alsayeqh, 2014). Other systems for surveillance and epidemiological investigation are currently under development by the Saudi Food and Drug Authority (Saudi Arabian Monetary Agency, 2013). Incidence rate means for a 5-year period from 2007-2011 for notifiable diseases and food poisoning (ill-defined) cases are shown in figure 1 (Ministry of Health, 2011).

It has been reported that more than $60 \%$ of foodborne diseases in KSA are caused by food prepared in restaurants (AlButhi, 2008; Al-Mutairi et al., 2014). In Riyadh city alone, an average of 55 foodservice establishments are involved in outbreak incidence annually. However, as is the case in many countries, foodborne diseases may be underdiagnosed or underreported in the KSA. Obtaining more accurate estimates for these diseases is hindered by the shortage of sufficient infrastructure and specialized scientists and staff. The majority of surveyed consumers in the KSA thought restaurants were responsible for the foodborne disease they experienced (Alsayeqh, 2014).

Throughout developed countries, the fundamentals of restaurant inspection are well established (Pilling et $a l ., 2008)$. Food safety inspections are carried out in foodservice operations (restaurants, cafes, street food stands, grocery stores, catering companies) with the goal of preventing operation-associated foodborne disease outbreaks (Jones et al., 2004; Rennie, 1994). Repeated food safety infractions are reportedly observed (FDA, 2009). Many studies have investigated such infractions and possible causes (Arendt, 2008, Riyadh Province Municipality. 2014) and worker motivations (Johnson, 2005) to implement better practices.

This paper presents a review regarding food safety infractions and fraud reported in restaurants in the KSA and possible factors affecting their continuity.

\section{Type of food safety infractions and fraud}

Food fraud is defined as deliberate and intentional tampering, substitution, or addition to food for economic gain. It also includes misrepresentation of food/ingredients or food packaging or misleading statements about food products (Spink and Moyer, 2011). Food fraud presents a risk to public health, and it is potentially more risky than other types of food risk due to the enormous number of possible contaminants/adulterants that can be introduced into fraudulent products (Spink and Moyer, 2011).

In restaurants, food safety infractions are considered crucial, significant, or minor. Contamination or adulteration of food are examples of crucial infractions that present an immediate health hazard to the public and are associated with foodborne illnesses (Noble et al., 2009). Significant infractions, which are indirectly related to food preparation and storage, potentially pose health risks. Use of an improper holding temperature is an example of such an infraction. Dirty floors or walls are examples of minor infractions that are unlikely to present immediate health risk (Noble et al., 2009).

In the KSA, the most common food safety infractions and fraud reported by Ministry of Municipality and Rural Affair's (MOMRA) inspectors (Ministry of Municipality and Rural Affairs, 2011; Ministry of Municipality and Rural Affairs. 2012; Ministry of Municipality and Rural Affairs, 2013) in restaurants (table 1) were mostly similar to findings in FDA studies but also include serious fraudulent attempts to sell food unfit for human consumption (e.g., expired or spoiled food). The observed infractions may have been the factors that led to most food poisoning cases reported to $\mathrm{MOH}$ (Ministry of Labor, 2014). The type of infraction and food consumed may assist in predicting the presence of microbial pathogens that can cause a foodborne disease (Jay et al., 1999). In the KSA, the cuisines most commonly consumed by citizens are meat (red meat, poultry, and fish) and rice, flour-based traditional dishes, and assorted sandwiches. These are multi-ingredient meals that require many preparation steps. Therefore, there are many contamination possibilities and opportunities to 
implement improper holding practices (Todd et al., 2008). For these cuisines, Salmonella spp., and Staphylococcus aureus have been commonly implicated in foodservice-originating foodborne diseases (AlButhi, 2008; Al-Mazrou, 2004; Tajkarimi et al., 2013). Additionally, ill-defined cases reported to $\mathrm{MOH}$ may have been caused mostly by Campylobacter jejuni, Bacillus cereus, Clostridium spp., and Escherichia spp. (Alsayeqh, 2014).

\section{Possible factors affecting food safety infraction and fraud continuity}

1.1 Restaurant general regulations and violation fines.

The MOMRA has issued a document (Ministry of Municipality and Rural Affairs, 2013) with requirements that need to be met when opening a restaurant. These requirements include general (location and size, building, restaurants divisions, storage, public area, and equipment), special (raw materials, food products, transportation, food storage, meal preparation, frozen food use, serving meals, general hygiene, health inspection records), and personnel categories (health certificates, contagious diseases and injury, and general appearance and behavior). The presence of a qualified manager of trained food handlers is not required.

Although these requirements are designed to assist in part in preparing and serving safer foods, infractions are repeatedly observed during inspection. The lenient fines restaurants are required to pay in the case of a violation may play an important role in their failure to meet the required standards and practices. The types of violations and fines imposed by MOMRA are shown in table 2.

During 2013, more than 350 restaurants were temporarily closed by Riyadh Province Municipality (RPM) in Riyadh after an intensive campaign against establishments that violated food safety protocols (Riyadh Province Municipality, 2014). Most restaurants reopened after paying the fines, which are considered a negligible fraction of annual profits. Similar campaigns throughout the KSA resulted in temporary closure of restaurants in violation of regulations. If this high number of businesses that repeatedly violate food safety rules occurs in Riyadh, the central location of government offices, the situation in other cities and villages may not be better.

The fine for a foodborne disease outbreak is only $\$$ 266/ affected customer for a first-time indictment with a maximum of $\$ 2666$ if a second outbreak occurs. There is no clear regulation indicating that restaurants must provide compensation to outbreak victims. In other countries, victims of foodborne illness outbreaks at restaurants can sue for compensation. Such legal suits can bankrupt a foodservice business (Cochran-Yantis et al., 1996).
The allowable compensation for unintentionally causing death set by the Saudi Council for Jurisdiction (SCJ) does not exceed \$ 107239 (Saudi Council for Jurisdiction, 2011). Currently, who would pay such compensation, especially if the indicted restaurant's operator cannot is not legally specified. As a step toward applying proper food safety practices, authorities should consider a more effective fine scheme.

\subsection{Food transportation.}

Most imported food products enter the country via the seaport at Jeddah (on the west coast) and Dammam (on the east coast). Trucks are used when importing foods from neighboring countries. Chilled meat and fresh fruits and vegetables are imported by air through the Riyadh and Jeddah airports (United States Department of Agriculture, 2013).

Some bulk food supplies (e.g., grains) are transported mainly by rail (Erera, 2005). Truck transportation remains the most common transportation, especially toward the consumer end of the food supply chain. It is used to move goods among manufacturers, wholesalers, retailers, and preparation establishments (Böge, 1997). Perishable food items are transported mostly by trucks. In the US, approximately $90 \%$ of cooled-truck transport is used for moving food, and $80 \%$ of all food shipments rely on trucks (Ackerley et al., 2010, United States Department of Agriculture, 2007). This percentage is expected to be higher in the KSA because there is only $1380 \mathrm{~km}$ of railways limited to connecting the eastern province's port to Riyadh.

The most commonly observed food safety hazards associated with food transportation are improper holding practices, improper temperature control, improper security procedures during transportation, practices leading to cross-contamination, and improper loading equipment/conditions. Others include poor driver's personal hygiene, lack of product traceability, poor maintenance of the transpiration unit, and lack of policy enforcing proper transportation (Ackerley et al., 2010).

In the KSA, where the summer temperature can average more than $40{ }^{\circ} \mathrm{C}$, improper food handling practices and unsuitable vehicles and equipment will result in higher microbial growth in foods. If proper food transportation is not employed, the effect of other food safety practices may be minimized. In the KSA, a driver with a truck driver's license can work transporting food. There are no additional requirements (e.g., food handling training, prior food transportation experience). Transporting food improperly has been reported as a common and repeated violation in the kingdom (table 1). Truck cargo weight regulations on highways, permitted driving hour windows within cities, long work hours, 
and untrained drivers are factors that may lead to food handling abuse during transport.

\subsection{Design and equipment.}

Preventing pathogen entrance into foodservice businesses is difficult because of size and design issues associated with these businesses. Building design, which is usually overlooked during inspection, can contribute to the incidence of an outbreak by facilitating the spread of pathogens throughout the premises (Giambrone, 2009). Inappropriate design can interfere with proper workflow and the application of hygienic practices. The design should take into consideration protection from contaminant introduction and transfer by aerosol, dust, pests, and dirt (Giambrone, 2009, Greig et al., 2007). Improper or unclean utensils have been implicated in reported outbreaks (Greig et al., 2007, Todd et al., 2008).

Although the requirements for a restaurant's location, building, and equipment are defined by MOMRA (Ministry of Municipality and Rural Affairs. 2014), it is currently possible for a commercial space, usually the ground floor of an office or residential building, to be outfitted and operated as a restaurant. Selfcontained restaurant buildings are generally operations of an international franchise. Proper workflow and practices may not be possible in a space that is not designed to be operated as restaurant. Improper general hygiene and pest and insect presence are two common violations (table 1) that may indicate that most restaurants in the KSA are poorly designed and fitted.

An open kitchen design that enables customers to observe food preparation is reported to positively influence cleanliness and employers' behavior in restaurants (Chow et al., 2010). Recently, MOMRA required that restaurants use a glass barrier between the kitchen and the serving area to allow customers to see workers preparing food. Noncompliant restaurants are fined and closed. In the KSA, It is questionable that visual observation will improve food safety in restaurants where workers commit fraud and other serious infractions (table 1).

\subsection{Restaurant workers.}

The restaurant industry has followed the model of "increasing profits based on practices that marginalize employees". Labor and work ethic regulations are often violated. Paying wages under the table, hiring without training, and denying rights are examples of these violations. Jobs in the restaurant sector are often offered with very low wages, few or no benefits, and limited opportunities for career advancement (Lo and Jacobson, 2011).

According to the Ministry of Labor (MOL), most private-sector jobs in the KSA are occupied by non-
Saudis (Ministry of Labor, 2014). This phenomenon could be observed partially because Saudis are not attracted to jobs with long work hours, low salaries, and no clear retirement plan. Of the total population, $32 \%$ are non-Saudi. Approximately $88.27 \%$ of private sector male workers in the country are non-Saudi. The majority of these workers are non-Arabic speaking and have limited or less than high school education (table 3) (Ministry of Labor. 2014).

Although Saudi Monetary Agency (SAMA) estimated that the number of non-Saudis employed in restaurants/cafes is approximately 250,343 (Saudi Arabian Monetary Agency, 2013), this number may represent only legally working employees. The frequent presence of illegal workers in restaurants indicates that the estimate of the total non-Saudi restaurant employees is highly underestimated.

Undercover trading costs the KSA economy an estimated $\$ 80$ billion a year. Because it is illegal for a non-Saudi to practice investing activities without permission, a non-Saudi may use a citizen's trade permission to do business in return for a monthly payment, which is considered undercover trading (AlMutairi, 2012). Most profits made from such business are transferred outside the country, including approximately $22 \%$ of the total money sent overseas by non-Saudi workers. Due to the ability of some businesses to obtain entry permits for hundreds or even thousands of workers, the number of entry permits has been estimated 1.2 million annually. Most of the coming workers change job and/or work illegally.

Restaurants, retail, and construction are the types of businesses mostly suspected to be practicing undercover trading and employing illegal workers (AlMutairi, 2012). These practices directly affect restaurant food safety. If an outbreak occurs at a restaurant that employs illegal workers, there is a low chance of investigating the cause of the outbreak. This is because illegal workers may leave the premises with the assistance of their employer when an inspector arrives for a visit. The MOMRA has also established a fine for those who assist escapee workers (table 2). Illegal workers may not apply food safety measures and could be responsible for food fraud violations. The government requires private businesses to employ a certain percentage of Saudis (Ministry of Labor, 2014) in its effort to minimize unemployment in the country. This resulted in an increase in fake job nationalization practices, in which a private employer hires a Saudi worker to increase the percentage of Saudis employed even though that worker does not actually come to work. It is not uncommon that many of the 91,183 Saudi workers (Saudi Arabian Monetary Agency. 2013) in restaurants are hired just to comply with the government requirement. Whatever the real number 
of actively working Saudis in restaurants is, they usually work as accountants and are not often food handlers.

\subsection{Worker health certificates.}

All workers entering the country are required to undergo medical examination before obtaining permission to stay and work (Ministry of Health, 2008). In the past, examinations were only accepted if they were performed in government-operated hospitals/health centers. With the increase in population and incoming workers, it has not been possible for government health systems to keep with increasing demands for laboratory services. Therefore, private sector health establishments have been allowed to perform worker health tests (Ministry of Health, 2008). This created competition among the establishments to attract more businesses to send workers for testing, resulting in a price-per-test drop under even the government laboratory costs. It is possible for a worker the required examination for less than $\$ 30$. This price decrease raised concerns about the ethics and integrity of services performed at private laboratories (AlSudan and Khan, 2008). These prices may not cover the basic costs of these laboratories. Therefore, a presumably valid health certificate displayed at the restaurant obtained on the basis of a private laboratory service may not mean that the worker is truly medically fit.

Government and private health care systems employ less than 20,000 people total, of which 1665 are laboratory-associated workers and 1665 are specialists (Ministry of Health, 2011). The overstretched health system may not capture workers with medical conditions of public health concern. Non-compliance with regulations has recently resulted in closure of some private-sector health service establishments (Ministry of Health, 2011).

\subsection{Worker salary and benefits.}

When employees lack motivation, it is expected that there will be problems in turnover and retention, morale, and productivity. In restaurants, employers must first understand their employees' motivations before utilizing ineffective techniques (Johnson, 2005).

For hourly restaurant workers, extrinsic motivation factors are important. These factors include good wages, good working conditions, tactful discipline, and job security. Additionally, intrinsic factors (a feeling of being involved, supervisor's help with personal problems, interesting work, promotion and career development, and appreciation of job well done) must be considered when surveying employees' motivational issues (Johnson, 2005; Kassa et al., 2001; Lo and Lamm, 2005; Wong et al., 1999).
Making employees feel that they are paid what they are worth is the postulation of Theory M, which is based on an above-average performance system (Weaver, 1988). Graduated incentives are paid for any amount achieved above a base of expected sales. Incentives need to be simply determined and paid out as soon goals are achieved. Paying employees what they are worth is argued to have effects different from those expected by raising the minimum wage (Weaver, 1988).

Restaurant customers may or may not tip workers depending on the social norms of their country. Tipping is considered another income source for millions of workers (Azar, 2003). The effect of pay, which may be not a motivator for all employees in different jobs (Rynes et al., 2004), is best modeled in a poorly performing businesses (Weaver, 1988).

Behavior, as determined by intention, which in turn is predicted by attitude, subjective norms, and perceived behavioral control, can be predicted by applying the theory of planned behavior (TPB) (Ajzen, 1991). Food safety practices in a foodservice operation, proper hand washing, consumer food handling practices, and food thermometer use have been predicted by TBP modeling (Clayton et al., 2002; Clayton, and Griffith, 2008; Mullan and Wong, 2009; Mullan et al., 2010; Shapiro et al., 2011).

Various studies have investigated theories and motivational factors such as incentives and tipping for workers who did not receive less than less than minimal wages. Before replicating such studies in a country where a minimum wage scheme is not applied, one may ask what might motivate an expatriate restaurant worker who receives less than \$ 11 a day to follow food safety measures. In the KSA, the labor law (Ministry of Labor, 2014) does not set a minimum-wage scheme for foreign workers. The MOL estimates that the average salary for a worker in the service sector is about $\$ 311$ per month (Ministry of Labor. 2014), which corresponds to $\$ 10.38$ a day and \$ 1.038 per hour, 5 times less than the less than minimal per-hour wage applied in other countries (Metcalf, 2008, Schmitt, 2013). The law also does not require other benefits for service workers such as medical insurance, housing allowances, paid sick leave or a weekly day off.

Working for long hours in restaurants and without benefits on a low salary may not motivate workers to comply with regulations or observe food safety practices. Tipping is not generally practiced in restaurants in the KSA. These factors could result in attempts to commit food fraud by some workers to supplement their income. Attempting to sell leftover, expired, or spoiled food are examples of commonly committed food fraud in restaurants in the KSA (table 1). 
In addition to the danger of questionable worker health certificates, low pay may prevent workers from taking day(s) off while sick. If a food worker does not receive paid sick leave, there is a possibility that this worker will continue to work (Strohbehn et al., 2008). A worker with gastroenteritis can show symptoms for a period ranging from days to months (Michael, 2002). After symptoms subside, shedding of the agent(s) can occur at a rate of $1-70 \%$ of affected persons (Michael, 2002). In a study investigating the carriage rate among food workers in restaurants, $34 \%$ of the workers were colonized, mostly with enterotoxigenic S. aureus (Fischer et al., 2007).

A sick working employee can put other employees and customers at risk (Todd et al., 2008). While employers may be unwilling to grant paid sick leave, working while sick can result much higher lost productivity time (Levin-Epstein, 2005). This is because an ill worker may perform poorly and infect others (Levin-Epstein, 2005). Contagious infection rates have been reported decrease by implementing a paid sick-leave policy. Failure to apply this policy would be detrimental to a worker's health, spread disease in the workplace, and could results in huge profit losses (Levin-Epstein, 2005). Food workers can be infected with pathogens that may be resident or transient flora (Nicolay et al., 2011). Sources of transient pathogen include raw products, fecal matter, body fluids and infected boils and cuts (Todd et al., 2008). Workers who are symptomatic or asymptomatic have been similarly implicated in foodborne disease outbreaks (Nicolay et al., 2011; Todd et al., 2008).

\subsection{Restaurant inspection.}

In Saudi Arabia, seven governmental authorities (table 4) are involved in issues related to food safety control in Saudi Arabia. They are MOMRA, Ministry of Agriculture (MOA), MOH, MOCI, Saudi Standards and Metrology Organization (SSMO), Customs Clearance Agency (CCA), and SFDA. The latter is the newest authority to be established, with the objective of centralizing and overseeing food and drug safety in the country. Many food safety responsibilities that the first six authorities dealt with in the past are now being gradually transferred to the SFDA (Al-Kandari, and Jukes, 2012; Al-Mutairi et al., 2014).

The MOA has been responsible for the quarantine of imported agri-foods and local product inspection. Retailers, wholesalers, restaurants, hotels, fast food chains, food factories, and fresh produce market inspections are primarily carried out by MOMRA. As of May 2009, imported food inspection became an SFDA and not MCI responsibility. When completely operational, SFDA will also carry out local food and foodservice operation inspections. Chemical and microbial analyses of food are performed in local laboratories that are now operating under SDFA supervision (Al-Kandari and Jukes, 2012).

Inspection reports can affect dining decisions and consumers' trust in restaurants. They can promote safe food culture by providing incentives for restaurants to obtain better scores (Fielding et al., 2001; Jin and Leslie, 2003; Simon et al., 2005; Worsfold and Worsfold, 2008). Disclosure systems for restaurant inspections are communication tools that deliver information obtained during restaurant inspections to consumers and to other relevant authorities. Making the inspection results publicly available puts more focus on the importance of violations and risks found during inspection (Seiver, and Hatfield, 2000).

Disclosure of inspection results can occur via the local media, internet, and posting at the premises. Information regarding unhygienic restaurants, outbreaks, convictions, and closure can be communicated using newspapers, radio and television (Henson et al., 2006). Restaurants meeting the required standards can also benefit from media influence on consumer dining choices (Gregory and Kim, 2005). The concern over food safety at restaurants can be affected by media images of pestinfested premises, improper food handling, and poor hygiene (Worsfold, 2006). Although word of mouth can be a source of information about restaurants and dining options (Gregory and Kim, 2005), media images and information are considered the most influential sources (Henson et al., 2006).

Inspection certificates posted at the premises do influence consumer choices and are considered an important source of information when dining out (Henson et al., 2006). In the UK, some restaurants post inspection scores or notices even though the local inspection department posts all inspection reports on its website (Worsfold and Worsfold, 2008). The majority of surveyed consumers wished for the inspection report to be available online and displayed at the premises (Worsfold and Worsfold, 2007).

Name-and-shame notices can be published on the authority's website for establishments that fail to correct risky conditions. Such notices remain posted for 3 months after corrections. A closure order is posted for restaurants in which public health is in immediate danger (Filion, and Powell,. 2009).

In the KSA, there are no full restaurant inspection reports available to the public in print or online forms. Consumers usually read about restaurant closures due to food safety violations in the local newspaper. However, newspapers are not allowed to publish the restaurant name or exact location. Closure news headlines mostly state the Arabic word "Shaheer", which translates to "popular or famous". 
This is because name-and-shame is not generally allowed in the KSA. However, due to the increase of restaurant-mediated foodborne outbreaks, MOMRA has allowed the use of a "Closed due food poisoning" sign at the restaurant in question.

Non-traditional mechanisms of dissemination of information such as the use of social media to communicate messages related to food safety have been reported (Bernardo et al., 2013, Brownstein et al., 2009). Individuals who have experienced foodborne illnesses may not seek medical care but might be willing to tell others about their experiences using social media platforms (Nsoesie et al., 2014.). In the KSA, newspapers are utilizing social media to communicate restaurant-related news to consumers. Consumers can obtain more details (e.g., restaurants names and locations) by messaging others. From 2011-2013, 42 outbreaks occurred in many "popular" restaurants, resulting in 821 people seeking medical attention. Other restaurants that did not receive media attention may also contribute greatly to incidences of notifiable foodborne diseases and to what the $\mathrm{MOH}$ classified as "food poisoning" cases that were reported to the surveillance system (figure 1).

\subsection{Food Inspectors.}

In KSA, there are less than 2500 health inspectors employed by MOMRA, which is primarily responsible for carrying out inspections of restaurants, food-sale stores, hotels, and other services that may affect public health. Clearly, this number of inspectors is unable to cover and perform inspections for all related sectors. This shortage became evident after MOMRA, which is presented in 285 municipalities throughout the country, has increased inspection visits to 5 times per establishment per year (Mullan and Wong, 2009). Given an estimated 2.5 hours for every inspection trip, 5 visits, and 1840 work hours each year, a minimum of 1932 inspectors is required to inspect only restaurants in the country. Currently, there are no private businesses employing inspectors through government contracts.

Although food inspectors have a major effect on public health, the job of inspector is among the lowest classified in the Ministry of Civil Service (Ministry of Civil Service, 2014). The salary for an inspector starts at $\$ 800$ and can reach $\$ 2288$ only after serving 15 years. Clearly, such a salary is such low to motivate inspectors to perform their jobs better. Additionally, given the low pay, there is a danger of accepting bribes from restaurants in violation of regulations.

Obtaining a diploma after intermediate or high school is generally the main requirement for working as an inspector. In addition to the shortage of inspectors, low salaries, and insufficient education/training, the real number of violating restaurants and quality of inspections performed are questionable. When no official government jobs openings are available, inspectors are hired by the government on a "paid contract" basis. This type of hiring requires fewer qualifications and pays lower salaries and benefits.

In Riyadh, 400 inspectors have applied to a training program sponsored by the Saudi Oil Company. Applicants attended one day of training followed by knowledge assessment. This was followed by 20 days of training in which 200 inspectors qualified for 3 more days of training (Riyadh Province Municipality, 2014). The fact that not all inspectors were qualified for the training is an indication of the lack of sufficient training for most inspectors currently working in the country.

Salaries and benefits vary for inspectors throughout government positions even if they are similarly qualified. Inspectors employed by $\mathrm{MOH}$ receive better pay and benefits more than those employed by MOMRA. These unequal differences have resulted in lawsuits filed against the SCCS by MOMRA's inspectors. If MOMRA inspector job pay and benefits are not improved, the inspector shortage is expected to grow in the future. Expansion of the foodservice sector by more than $5 \%$ a year will result in requirements for more workers and inspectors (Saudi Arabian Monetary Agency, 2013). To maximize efforts toward better food safety in the country, inspector qualifications must be enhanced and job benefits improved.

\subsection{Worker training.}

High-quality training is essential to obtaining the desired improvement. Improper or inadequate information given by insufficiently qualified instructors or the wrong information given to trainees can result in more improper food handling (Rennie, 1994). Basic knowledge about food safety can be affected by the source of the training, certification, and experience (Lynch et al., 2003). Quality, not quantity, is considered to be more important for understanding issues related to food safety (Lynch et al., 2003).

Promoting food safety practices can be attained by worker training and enforcement and implementation of management systems (Mitchell et al., 2007; Rennie, 1995). Factors influencing employees' foodhandling practices have been addressed by many studies (Arendt and Sneed, 2008; Ellis et al., 2010). Identified factors include but are not limited to time constraints, resource shortages, and management and coworker attitudes, generational differences, language, lack of motivation, and illiteracy (Green et al., 2006; Howells et al., 2008; Pragle et al., 2007). Such factors extend beyond food safety knowledge; researchers found that food service employee's practices do not always reflect demonstrated 
knowledge of food safety (Giampaoli et al., 2002; Henroid, and Sneed, 2004; Strohbehn et al., 2011). Transfer of obtained food safety knowledge, skills, attitudes, and behavior during training can be limited by the factors mentioned above. Approximately $85 \%$ of respondents with training certification admitted that they do not apply their knowledge in practice (Clayton et al., 2002).

Compared to restaurants with certified food handlers, more food safety infractions were observed in restaurants without such handlers (Kassa et al., 2001). At least one critical infraction was observed in almost all food service establishments operating without certified handlers (Kassa et al., 2001).

In studies investigating the effect of food safety training on employees, overall enhancements of food safety knowledge were observed (Costello et al., 1997; Finch and Daniel, 2005; Howes et al., 1996; Lynch et al., 2003). These observations were not consistent with those of other studies that reported a minimal effect of training on knowledge improvement (Luby et al., 1993; Pilling et al., 2008; Wright and Feun, 1986).

Increased proper practice among employees, better microbial food quality, higher food-inspection scores, and hygienic self-reported behavior were noticed among those who received food safety training (Thompson et al., 2005). During an inspection, a foodservice operation with at least one certified food handler was more likely to obtain a passing grade (Thompson et al., 2005). Because food safety training may not be possible for all employees, training establishment supervisors has been reported to have a positive effect on employees' food safety practices.

In the KSA, the plan for training restaurants employees initially started in 2009 in the eastern province of the KSA. By 2013, the staff of 171 (out of 440) restaurants had been trained and designated "qualified". The effect of training on these restaurants employees remains to be determined. For training restaurant employees to have better outcomes or even be applied by employees, it is necessary to improve salary, benefits, and work conditions.

\subsection{Foodborne disease surveillance.}

The objectives of foodborne disease surveillance programs include rapid response to outbreaks, applying measures to prevent illness, identifying contributing factors, outbreak trends monitoring, increasing knowledge about foodborne disease, and preventing future outbreaks (Council to Improve Foodborne Outbreak Response, 2014). Irrespective of the outbreak scale, a full investigation should include an epidemiological investigation, food and environmental investigations, and laboratory investigations. (Council to Improve Foodborne Outbreak Response, 2014).

In 2008, a study was carried out regarding foodborne investigation in the KSA (AlButhi, 2008). The findings indicated that the methods and procedures applied during an outbreak investigation were incorrect or inadequate. Since that study was conducted, there has been no significant improvement regarding training and regulations related to outbreak investigation. However, the situation is expected to be corrected when the SFDA completely brings all issues regarding food safety under its supervision. Special departments have been established within the SFDA to investigate foodborne outbreaks (Saudi Food and Drug Authority, 2014). When it is fully staffed with specialists and operational, obtaining more accurate epidemiological information about outbreaks may be possible.

\subsection{Consumer protection.}

The Consumer Protection Association (CPA) was not established until 2007. The CPA was established as a non-legislative association without an annual governmental budget. Currently, the main roles for the CPA include receiving consumer complaints about products or services, informing other government's authorities about consumer concerns, performing research related to consumer protection, and representing consumers in related conferences and events (Consumer Protection Association, 2008).

To be able to have an effective role in protecting consumers' rights when affected by a foodborne outbreak, CPA status shall be a legislative authority with an annually guaranteed budget. Although there is a royal decree demanding that commerce chambers contribute to CPA's expenses, the CPA has not yet received its expected funding (Makkah Commerce Chamber, 2014).

\subsection{Consumer awareness.}

The websites of government authorities involved in food safety issues were searched for information concerning consumer education about food safety in restaurants. Only 2 results related to advice about plastic ware used in restaurants and eating while traveling were found on the SFDA's website (Saudi Food and Drug Authority, 2014). On the CPA's website, only one result was found, but it was important; it covered a call to boycott an international franchise restaurant indicted on attempt to use expired and spoiled material in preparing meals. Specifically, CPA named the restaurant, which was not possible in the past (Consumer Protection Association, 2012). A search on MOMRA's website found 52 publications related to food safety. These publication can benefit consumers, investors, restaurants workers (if translated), and inspectors (Ministry of Municipality and Rural Affairs, 2014). The only restaurant- 
awareness advice posting was found from the Food Safety Program, which is a part of the MOH (Food Safety Program, 2014).

Because studies found that offering public access to restaurant inspection reports can cause restaurants to improve their food safety practices (Filion, and Powell, 2009; Henson et al., 2006; Worsfold and Worsfold, 2008), it is recommended that the SFDA,
CPA, MOMRA,MOH, and MOCI utilize the internet to communicate with consumers regarding restaurant inspections and advise them when dining out. For increased awareness to be effective, generic prescriptive messages should be avoided. Consumer education needs to be specified for the target audience (Chapman et al., 2011).

Table 1: Food safety Infractions and fraud observed in restaurants in KSA.

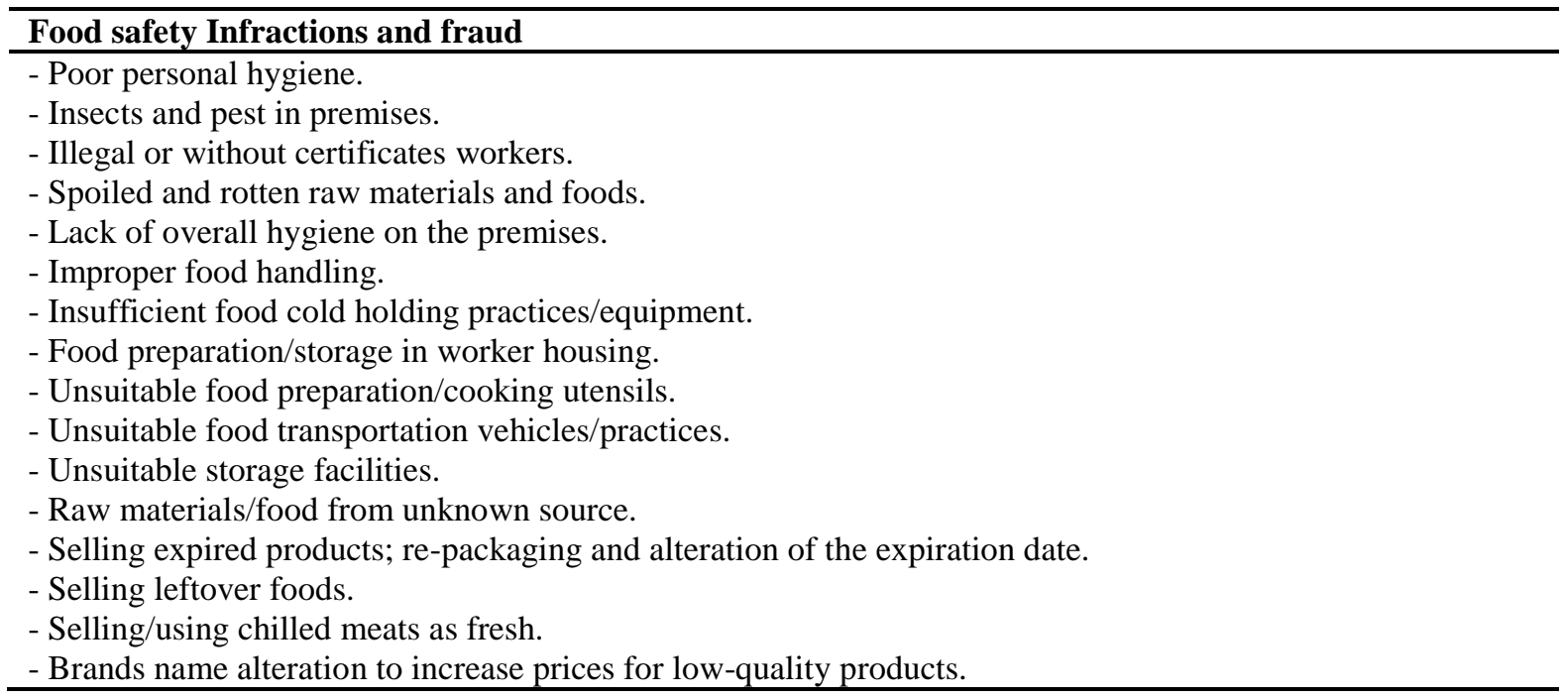

Table 2: Fines for violations in restaurants.

\begin{tabular}{|c|c|c|}
\hline Violation & Fine (\$) & Action for repeated violations \\
\hline Building & 133 & Double fine and 3 days closure \\
\hline Equipment & 133 & Double fine and 7 days closure \\
\hline \multicolumn{3}{|l|}{ Restaurants' workers } \\
\hline Without valid health certificate & 133/ worker & Double fine for every worker \\
\hline Workers with visible sign of a disease & 266/ worker & Double fine and 7 days closure \\
\hline Poor personal hygiene & $80 /$ worker & Double fine \\
\hline Not wearing designated uniform & 26/ worker & Double fine \\
\hline \multicolumn{3}{|l|}{ Food, water, and drinks } \\
\hline Use of expired materials & 2666 & Double fine \\
\hline Improper storage & 266 & Double fine \\
\hline Improper transportation and packaging & 533 & Double fine \\
\hline Use of leftover foods & 533 & Double fine \\
\hline Food from unknown source & 533 & Double fine \\
\hline Food with visible spoilage & 533 & Double fine \\
\hline \multicolumn{3}{|l|}{ Inspection process } \\
\hline Obstructing inspectors work & 133 & Double fine \\
\hline $\begin{array}{l}\text { Removal of "closed due to food } \\
\text { poisoning" sign }\end{array}$ & 1333 & Double fine \\
\hline $\begin{array}{l}\text { Assisting escape of illegal workers before } \\
\text { inspection }\end{array}$ & $\begin{array}{l}266 / \\
\text { worker }\end{array}$ & Double fine \\
\hline Food preparation outside the premises & 133 & Double fine \\
\hline \multicolumn{3}{|l|}{ General hygiene } \\
\hline Overall poor hygiene & 52 & Double fine \\
\hline \multicolumn{3}{|l|}{ Permit } \\
\hline Operation without permit & 533 & 2666 and closure \\
\hline Foodborne illness incidence & 266-2666/ person & $\begin{array}{l}\text { Closure for } 30 \text { days, and for } 5 \text { years after } \\
\text { second incidence }\end{array}$ \\
\hline
\end{tabular}


Table 3: KSA related statistics.

\begin{tabular}{|c|c|}
\hline Population (annual growth \%) & $29994272(2.7)$ \\
\hline Size $\left(\mathrm{km}^{2}\right)$ & 2.25 million \\
\hline$\%$ of non-Saudi residents & 32.41 \\
\hline Illiterate $\%$ & 5.6 \\
\hline GDP & $\$ 710.93$ billion \\
\hline Imported food products & 22 billion ( $7.65 \%$ increase from previous year) $\$$ \\
\hline Highways (under preparation) & $60336 \mathrm{~km}(22000 \mathrm{~km})$ \\
\hline Railways (km) & 1380 \\
\hline Number of non-Saudi male workers ( $\%$ in private sector) & $8050457(88.27)$ \\
\hline Education & $\%$ \\
\hline Higher education & 8.6 \\
\hline High school or less & 32 \\
\hline With training after high school & 7.26 \\
\hline Limited skills (and may be illiterate) & 52.14 \\
\hline Language spoken & $\%$ \\
\hline Arabic & 28.1 \\
\hline Non-Arabic & 71.9 \\
\hline \multicolumn{2}{|l|}{ Number of workers in restaurants } \\
\hline Non-Saudi & 250343 \\
\hline Saudi & 91183 \\
\hline Estimated annual increase in number of workers $(\%)$ & $5.54 \%$ \\
\hline
\end{tabular}

Table 4: Authorities involved in food safety and their roles in the KSA.

\begin{tabular}{ll}
\hline Authority & Responsibilities \\
\hline MOMRA & Licenses foodservice establishments, food inspection, participation in outbreak investigation. \\
\hline MOA & Farm food production issues, analysis of imported animals and vegetables. \\
\hline MOH & Foodborne outbreaks (investigation, training staff, consumer education). \\
\hline MOCI & $\begin{array}{l}\text { Participation in food safety and quality, fraud prevention, examination of imported food, local food } \\
\text { inspection. }\end{array}$ \\
\hline SSMO & \begin{tabular}{l} 
Participation in licensing of food premises; sets standards for product safety and quality. \\
\hline CCA
\end{tabular} \\
\hline Prevent fraudulent product entry. \\
\hline
\end{tabular}


Figure 1: Notifiable foodborne diseases and food poisoning incidence rate means.

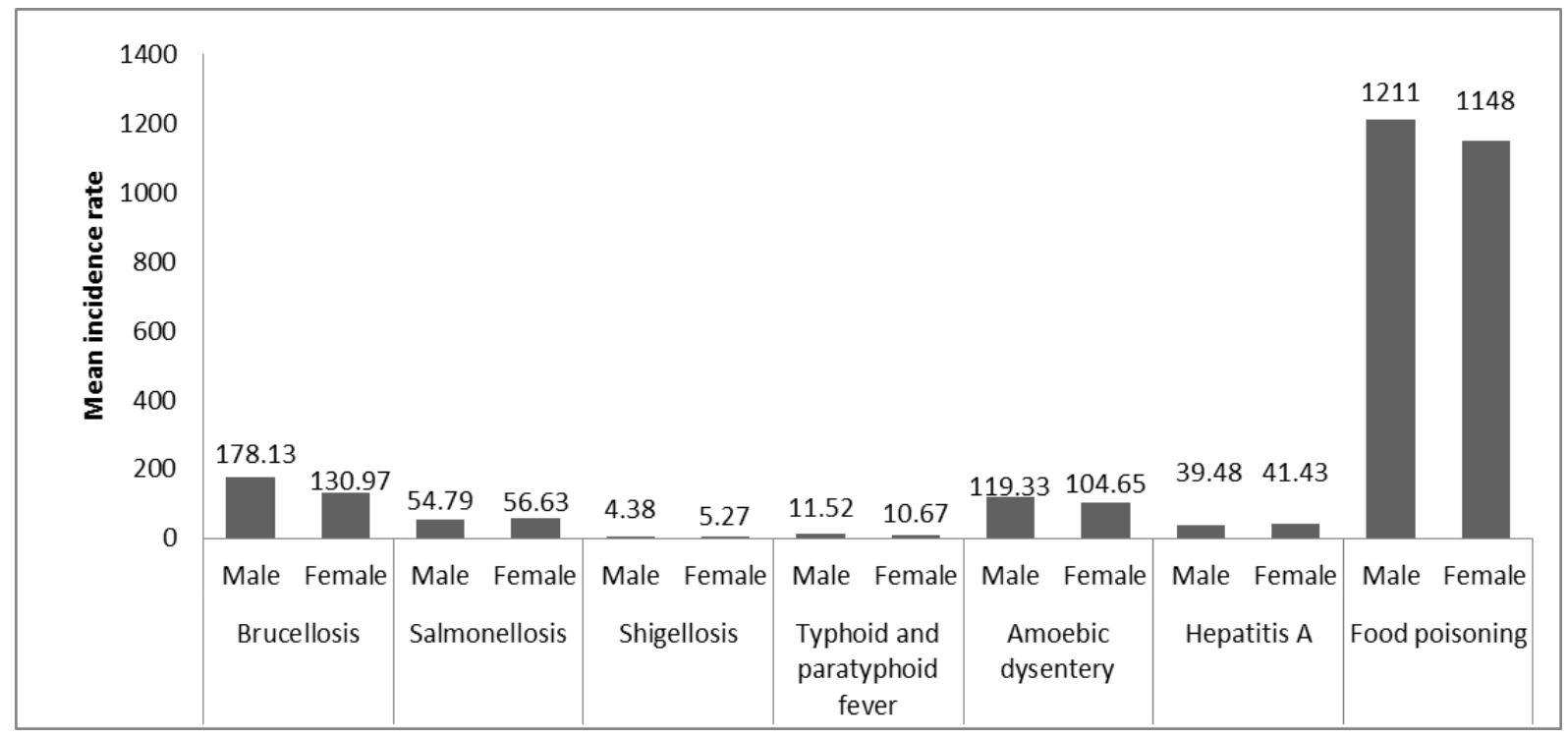

\section{CONCLUSIONS}

Serious food safety infractions and fraud are repeatedly observed in many restaurants in the KSA. Factors that may lead to these violations include illegal labor, low salaries for workers/inspectors, insufficient education for workers/inspectors, and governmental shortcomings (e.g., low fines, disease surveillance issues, and consumer awareness). To improve food safety in the country, effort needs to be made to minimize restaurant violations by eliminating these contributing factors.

\section{ACKNOWLEDGMENTS}

This work was made possible by the support of Qassim University.

\section{REFERENCES}

Ackerley, N.; Sertkaya, A. and Lange, R. (2010): Food Transportation Safety: characterizing risks and controls by use of expert. Food Prot. Trends. 30: 212-222.

AlButhi, S. (2008): Foodborne diseases surveillance. Unpublished data. Riyadh Province Municipality.

Al-Goblan, A.S. and Jahan, S. (2006): Surveillance for foodborne illness outbreaks in Qassim, Saudi Arabia. Foodborne Pathog. Dis. 7: 1559-1562.

Al-Kandari, D. and Jukes, D.J. (2012): The food control system in Saudi Arabia- Centralizing food control activities. Food Control. 28: 3346.

Al-Mazrou, Y.Y. (2004): Food poisoning in Saudi Arabia. Potential for prevention?. Saudi Med. J. 25: 11-14

AlMutairi, H. (2012): Measurement of undercover economy and its effect on total economic variables in Saudi Arabia from 1970-2009. Unpublished doctoral dissertation. Umm AlQura University. Makkah, Saudi Arabia.

Al-Mutairi, S.; Connerton, I. and Dingwall, $R$. (2014): Food safety organisations in Saudi Arabia organisational, historical and future analysis. Food Control 47: 478-486.

Alsayeqh, A.F. (2014): Foodborne disease risk factors among women in Riyadh, Saudi Arabia. Food Control.50: 85-91.

AlSudan and Khan. (2008): Regarding labor health examination in private laboratories. Unpublished raw data, Ministry of Health, Saudi Arabia.

Ajzen, I. (1991): Attitudes, personality and behavior. Milton Keynes: Open University Press.

Arendt, S.W. and Sneed, P.J. (2008): Employee motivators for following food safety practices: Pivotal role of supervision. Food Prot. Trends. 28: 704-711.

Azar, O. (2003): The implications of tipping for economics and management. Int. J. Soc. Econ. 30: 1084-1094.

Bean, N. and Griffin, P. (1990): Foodborne disease outbreaks in the United States, 1973-1987; pathogens, vehicles, and trends. J. Food Protect. 53: 804-817.

Bernardo, T.M.; Rajic, A.; Young, I.; Robiadek, K.; Pham, M.T. and Funk, J.A. (2013): Scoping review on search queries and social media for 
disease surveillance: a chronology of innovation. J. Med. Inter. Res.15: e147.

Birkhead, G.S.; Morse, D.L.; Levine, W.C.; Fudala, J.K.; Kondracki, S.F.; Chang, H.-G.; Shayegani, M.; Novick, L. and Blake, P.A. (1993): Typhoid fever at a resort hotel in New York: a large outbreak with an unusual vehicle. J. Infect. Dis. 167: 1228-1232.

Brownstein, J.S.; Freifeld, C.C. and Madoff, L.C. (2009): Digital disease detection-harnessing the web for public health surveillance. New Eng. J. Med. 360: 2153-2157.

Bruhn, C.M. (1997): Consumer concerns: motivating to action. Emerg. Infect. Dis. 3: 511-515.

Burslem, C.D.; Kelly, M.J. and Preston, F.S. (1990): Food poisoning - a major threat to airline operations. J. Soc. Occup. Med. 40: 97-100.

Böge, S. (1997): Freight transport, food production and consumption in the United States and Europe: or how far can you ship a bunch of onions in the United States? Wuppertal Paper No. 56.s, Wuppertal Institute for Climate, Energy and Environment, Wuppertal, Germany.

Centers for Disease Control and Prevention. (2006): Surveillance for foodborne disease outbreaks in United States, 1998-2002. Morb. Mort. Weekl. Rep. 55: 1-42.

Centers for Disease Control and Prevention., (2005): Preliminary FoodNet data on the incidence of infection with pathogens transmitted commonly through food-10 states, United States, 2005. Morb. Mort. Weekl. Rep. 55: 392-395.

Chapman, B.; MacLaurin, T. and Powell, D. (2011): Food safety infosheets. Brit. Food J. 113: 160186.

Chow, A.J.; Alonso, A.D.; Douglas, A.C. and O'Neill, A.M. (2010): Exploring open kitchens' impact on restaurateurs' cleanliness perceptions. J. Ret. Leis. Prop. 9: 93-104.

Clayton, D.; C.J. Griffith, P. Price, and A. C. Peters. 2002. Food handlers' beliefs and self-reported practices. Int. J. Environ. Health Sci. 12: 2539.

Clayton, D.A. and Griffith, C.J. (2008): Efficacy of an extended theory of planned behavior model for predicting caterers' hand hygiene practices. Int. J. Environ. Health Res. 18: 83-98.

Cramer, E.H.; Gu, D.X. and Durbin, R.E. (2003): Diarrheal disease on cruise ships, 1990-2000: the impact of environmental health programs. Am. J. Prev. Med. 24: 227-233.

Cochran-Yantis, D.; Belo, P.; Giampaoli, J.; McProud, L.; Everly, V. and Gans, J. (1996): Attitudes and knowledge of food safety among Santa Clara County, California restaurant operators. J. Foodser. Sys. 9: 117-128.
Collins, J.E. (1997): Impact of changing lifestyles on the emergence/reemergence of food-borne pathogens. Emer. Infect. Dis. 3: 471-479.

Consumer Protection Association. (2008): Establishment and mission. Available online at: http://cpa.org.sa/?page_id=20 .Accessed March, 9, 2014.

Consumer Protection Association. (2012): News. Available online at: http://cpa.org.sa/? news=746. Accessed March, 9, 2014.

Costello, C.; Gaddis, T.; Tamplin, M. and Morris, W. (1997): Evaluating the effectiveness of two instructional techniques for teaching four food safety principles to quick service employees. J. Foodser. Sys. 10: 41-50.

Council to Improve Foodborne Outbreak Response. (2014): Performance Indicators for Foodborne Disease Programs. Available online at: http:/www.cifor.us/documents/CIFORGuidelin esChapter8.pdf . Accessed May, 29, 2014.

Ellis, J.; Arendt, S.; Strohbehn, C.; Meyer, J. and Paez, P. (2010): Influencing safe food handling practices: The relationship between demographic characteristics and the efficacy of different motivator types at improving employees' safe food handling practices. J. Food Prot. 73: 2065-2071.

Erera, A. (2005): Providing security to food transportation systems without compromising productivity. Proceedings of the Institute of Food Technologists' first annual food protection and defense research conference, Atlanta, GA. Available online at: http://www.ift.org/ /media/Knowledge $\% 20$ Center/Science\%20Reports/Conference\%20Pa pers/21Erera.pdf . Accessed April, 12, 2014.

Fone, D.L.; Lane, W. and Salmon, R.L. (2001): Investigation of an outbreak of gastroenteritis at a hospital for patients with learning difficulties. Commun. Dis. Pub. Health. 2: 3538.

Food and Drug Administration. (2009): Report on the occurrence of foodborne illness risk factors in selected institutional foodservice, restaurant, and retail food store facility types. Available at: http://www.fda.gov/downloads/Food/ Guidance Regulation/RetailFoodProtection/ Foodborne $\quad$ Illness $\quad$ RiskFactor Reduction/UCM224682.pdf. Accessed May, 15, 2014.

Food Safety Program. (2014): Advise on dining at restaurants. Available online at: http://foodsafety-sa.com/Arabic/Vedio/ Pages/Prints.aspx. Accessed June, 9, 2014.

Fielding, J.E.; Aguirre, A. and Palaiologos, E. (2001): Effectiveness of altered incentives in a food safety inspection program. Prev. Med. 32: 239-244.

Filion, K. and Powell, D.A. (2009): The use of restaurant inspection disclosure systems as a 
means of communicating food safety information. J. Food Serv. 20: 287-297.

Finch, C. and Daniel, E. (2005): Food safety knowledge and behavior of emergency food relief organization workers: Effects of food safety training intervention. J. Environ. Health. 67: 30-34.

Fischer, A.R.; De Jong, E.D.; Van Asselt, R.; De Jonge, L.; Frewer, J. and Nauta, M. (2007): Food safety in the domestic environment: an interdisciplinary investigation of microbial hazards during food preparation. Risk Anal. 27: 1065-1082.

Friedman, D.S.; Heisey-Grove, D.F.; Argyros, E.; Berl, J.; Nsubuga, T.; Stiles, J.; Fontana, R.S.; Beard, S.; Monroe, M.E.; McGrath, H.; Sutherby, R.C.; Dicker, A.; DeMaria, Jr. and Matyas, B.T. (2005): An outbreak of norovirus gastroenteritis associated with wedding cakes. Epidem. Infect. 133: 1057-1063.

Giambrone, C. (2009): Critical sanitation issues in food service. Food Qual. 16: 35-38.

Giampaoli, J.; Cluskey, M. and Sneed, J. (2002): Developing a practical tool for assessing employee food handling practices. J. Child Nutri. Manag. 26. Available at: http://docs.schoolnutrition.org/ newsroom/ jcnm/02spring/giampaoli2/. Accessed May, 25, 2014.

Gotz, H.; de Jong, B.; Lindback, J.; Parment, P.A.; Hedlund, K.O.; Torven, M. and Ekdahl, K. (2002): Epidemiological investigation of a food-borne gastroenteritis outbreak caused by Norwalk-like virus in 30 day-care centres. Scand. J. Infect. Dis. 34: 115-121.

Green, L.; Selman, C.; Radke, V.; Ripley, D.; Mack, J.; Reimann, D.; Sagger, T.; Motsinger, M. and Bushnell, L. (2006): Food worker hand washing practices: An observational study. J. Food Prot. 69: 2417-2423.

Gregory, S. and Kim, J. (2005): Restaurant choice: the role of information. J. Foodserv. Busin. Res. 7: 81-95.

Greig, J.D.; Todd, C.D.; Bartleson, C.A. and Michaels, B.S. (2007): Outbreaks where food workers have been implicated in the spread of foodborne disease. Part 1. Description of the problem, methods, and agents involved. J. Food Prot. 70: 1752-1761.

Henroid, D. and Sneed, J. (2004): Readiness to implement hazard analysis and critical control point (HACCP) systems in Iowa schools. J. Am. Diet. Assoc. 104: 180-185.

Henson, S.; Majowicz, S.; Masakure, O.; Sockett, P.; Jones, A.; Hart, R. and Knowles, L. (2006): Consumer assessment of the safety of restaurants: the role of inspection notices and other information cues. J. Food Safety 26: 275-301.
Howes, M.; McEwan, S.; GriYths, M. and Harris, L. (1996): Food handler certification by home study: measuring changes in knowledge and behavior. Dairy Food Environ. Sanit. 16: 737744.

Howells, A.D.; Roberts, K.R.; Shanklin, C.W.; Pilling, V.K.; Brannon, L.A. and Barrett, B.B. (2008): Restaurant employees' perceptions of barriers to three food safety practices. J. Am. Diet. Assoc. 108: 1345-1349.

Jacob, C. and Powell, D. (2009): Where does foodborne illness happen - the home, food service, elsewhere-and does it matter?. Foodborne Pathog. Dis. 6: 1121-1123.

Jay, L.S.; Comar, D. and Govenlock, L.D. (1999): A National Australian food safety telephone survey. J. Food Prot. 62: 921-928.

Jin, G.Z. and Leslie, P. (2003): The effect of information on product quality: evidence from restaurant hygiene grade cards. Quart. J. Econ. 118: 409-451.

Jones, T.F. and Angulo, F.J. (2006): Eating in restaurants: A risk factor for foodborne disease? Clinic. Infect. Dis. 43: 1324-1328.

Jones, T.F.; Boris, I.P.; LaFleur, B.J.; Ingram, A. and Schaffer, W. (2004): Restaurant inspections scores and foodborne diseases. Emer. Infect. Dis. 10: 688-692.

Johnson, C.R. (2005): Employee motivation: a comparison of tipped and non-tipped hourly restaurants employees. (Doctoral dissertation, University of Central Florida Orlando, Florida). Available online at: http://etd.fcla.edu/CF/CFE0000847/Johnson_C atherine_R_200512_MS.pdf.pdf . Accessed April, 2, 2014.

Kassa, H.K.; Harrington, B.; Bisesi, M. and Khuder, $S$. (2001): Comparisons of microbiological evaluation of selected kitchen areas with visual evaluation for preventing potential risk of foodborne outbreaks in food service operations. J. Food Prot. 64: 509-513.

Latham, R.H. and Schable, C.A. (1982): Foodborne hepatitis $A$ at a family reunion. Use of IgM specific hepatitis A serologic testing. Am. J. Epidemiol. 115: 640-645.

Lee, M. and Middleton, D. (2003): Enteric illness in Ontario, Canada, from 1997 to 2001. J. Food Prot. 66: 953-961.

Levin-Epstein, J. (2005): Presenteeism and paid sick days. Center for Law and Social Policy, Washington, D.C. Available at: http://www.clasp.org/resources-andpublications/files/0212.pdf .Accessed March, 22, 2014.

Lo, J. and Jacobson, A. (2011): Human Rights from Field to Fork: Improving labor conditions for food-sector workers by organizing across boundaries. Race/Ethnicity: Multidisciplinary Global Contexts. 5: 61-82. 
Lo, K. and Lamm, F. (2005): Occupational stress in the hospitality industry: An employment relations perspective. New Zeal. J. Employ. Rel. 30: 23-47.

Luby, S.P.; Jones, J. and Horan, J. (1993): A large Salmonellosis outbreak associated with a frequently penalized restaurant. Epidemiol. Infect 110: 31-39.

Lynch, R.A.; Elledge, B.L.; Griffith, C.C. and Boatright, D.T. (2003): A comparison of food safety knowledge among restaurant managers, by source of training and experience, in Oklahoma County, Oklahoma. J. Environ. Health. 66: 9-14.

Makkah Commerce Chamber. 2014. Economic news. Available online at: http://www.makkahcci. org.sa/topics/Details/2119. Accessed July, 17, 2014.

Medeiros, L.C.; Hillers, V.N.; Kendall, P.A. and Mason, A. (2001): Food safety education: what should we be teaching to consumers?. J. Nutri. Edu. 33: 108-113.

Metcalf, D. (2008): Why has the British national minimum wage had little or no impact on employment?. J. Indust. Rel. 50: 489-512.

Michino, H. and Otsuki, K. (2000): Risk factors in causing outbreaks of food-borne illness originating in school lunch facilities in Japan. J. Vet. Med. Sci. 62: 557-560.

Michael, B. (2002): Handling money and serving ready-to-eat food. Food Ser. Techn. 2: 1-3.

Ministry of Civil Service. (2014): Regulations. Available online at: http://www.mcs.gov.sa /Archiving Library/Regulations/Pages/default. aspx?PageIndex=3 .Accessed March, 2, 2014.

Ministry of Labor. (2014): The labor law. Available at: http://portal.mol.gov.sa/en/ Pages/Labor Law.aspx. Accessed June, 23, 2014.

Ministry of Health. (2011): Yearly statistical books. Available on line at: http://www.moh.gov. sa/Ministry/Statistics/Book/Pages/default.aspx. Accessed February, 22, 2014.

Ministry of Health. (2008): Regulations. Available on line at: http://www.moh.gov.sa/Ministry/ Pages/default.aspx. Accessed February, 5, 2014.

Ministry of Municipality and Rural Affairs. (2011): Restaurants inspection report. Unpublished data.

Ministry of Municipality and Rural Affairs. (2012): Restaurants inspection report. Unpublished data.

Ministry of Municipality and Rural Affairs. (2013): Restaurants inspection report. Unpublished data.

Ministry of Municipality and Rural Affairs. (2014): Citizens services. Available at: http://www.momra.gov.sa/GeneralServ/Forms. aspx?id=1 . Accessed June, 22, 2014.
Mitchell, R.; Fraser, A. and Bearon, L. (2007): Preventing food-borne illness in food service establishments: Broadening the framework for intervention and research on safe food handling behaviors. Int. J. Environ. Health Res. 17: 9-24.

Mullan, B. and Wong, C.L. (2009): Hygienic food handling behaviours. An application of the Theory of Planned Behaviour. Appetite: 757761.

Mullan, B.; Wong, C.L. and O'Moore, K. (2010): Predicting hygienic food handling behaviour: modeling the health action process approach. Brit. Food J. 112: 1216-1229.

National Restaurant Association (2008): Restaurant Industry Forecast, 2007. 1-36 Washington, DC.

Nicolay, N.; McDermott, R.; Kelly, M.; Gorby, M.; Prendergast, T.; Tuite, G.; Coughlan, S.; McKeown, P. and Sayers, G. (2011): Potential role of asymptomatic kitchen food handlers during a food-borne outbreak of norovirus infection, Dublin, Ireland, March 2009. Eurosurveillance 16: (30). Available online at: http://www.eurosurveillance.org/images/dyna mic/EE/V16N30/V16N30.pdf. Accessed April, 16, 2014.

Noble, S.; Griffiths, M.; Thompson, S. and Maclaurin, $T$. (2009): Frequency and type of food safety infractions in food establishments with and without certified food handlers. Food Prot. Trends, 37: 840-848.

Nsoesie, E.O.; Gordon, S.A. and Brownstein, J.S. (2014): Online reports of foodborne illness capture foods implicated in official foodborne outbreak reports. Prev. Med. 67: 264-269.

Pilling, V.K.; Brannon, L.A.; Shanklin, C.W.; Roberts, K.R.; Barret, B.B. and Howells, A.D. (2008): Food safety training requirements and food handlers' knowledge and behaviors. Food Prot. Trends 28: 192-200.

Pragle, A.S.; Harding, A.K. and Mack, J.C. (2007): Food workers' perspectives on hand washing behaviors and barriers in the restaurant environment. J. Environ. Health 69: 27-32.

Rennie, M.D. (1994): Evaluation of food hygiene education. Brit. Food J. 96: 20-25.

Rennie, M.D. (1995): Health education models and food hygiene education. J. Royal Soc. Health 115: 75-79.

Riyadh Province Municipality. (2014): News. Available online at: http://www.riyadh. gov.sa/ar/Pages/Home.aspx. Accessed June, 11, 2014.

Roberts, K. R., Barret, B. B., Howells, A. D., Shanklin, C. W., Pilling, V. K., and Brannon, L. A. 2008. Food safety training and foodservice employees' knowledge and behavior. Food Prot. Trends 28: 252-260. 
Rynes, S.L.; Gerhart, B. and Minette, K.A. (2004): The importance of pay in employee motivation: discrepancies between what people say and what they do. Human Resource Manag. 43: 381-394.

Saudi Arabian Monetary Agency (2013): Year 2013 statistical report. Available online at: http://www.sama.gov. sa/ReportsStatistics/ReportsStatisticsLib/5600_ R_Annual_Ar_49_2013_12_23.pdf . Accessed May, 19, 2014.

Saudi Food and Drug Authority (2014): Food sector departments. Available online at: http://www.sfda.gov.sa/ar/food/about/administ ration/Pages/default.aspx. Accessed May, 19, 2014.

Schmitt, J. (2013): Why does the minimum wage have no discernible effect on employment? Center for Economic and Policy Research. Available online at: http://dev. takeactionminnesota.org/wp-content/uploads/ 2013/10/Why-Does-the-Minimum-Wage-Have -No-Discernible-Effect-on-Employment. pdf. Accessed March, 17, 2014.

Saudi Council for Jurisdiction (2011): Re-assessment for manslaughter compensations amount. Available online at: http://www.scj.gov. $\mathrm{sa} / \mathrm{index} \cdot \mathrm{cfm} ? \mathrm{do}=\mathrm{cms}$.conArticle \& contentid $=1$ 092\&categoryid=443. Accessed March, 13, 2014.

Seiver, O.H. and Hatfield, T.H. (2000): Grading Systems for Retail Food Facilities: A RiskBased Analysis. J. Environ. Health 63: 22-33.

Shapiro, M.A.; Porticella, N.; Jiang, L.C. and Gravani, R.B. (2011): Predicting intentions to adopt safe home food handling practices. Applying the theory of planned behavior. Appetite 56: 96-103.

Simon, P.A.; Leslie, P.; Run, G.; Jin, G.Z.; Reporter, R.; Aguirre, A. and Fielding, J.E. (2005): Impact of restaurant hygiene grade cards on foodborne-disease hospitalizations in Los Angeles County. J. Environ. Health 67: 32-36.

Spink, J. and Moyer, D.C. (2011): Defining the public health threat of food fraud. J. Food Sci. 76: R157-63.

St. Louis, M.E.; Porter, J.D.; Helal, A.; Drame, K.; Hargrett-Bean, N.; Wells, J.G. and Tauxe, R.V. (1990): Epidemic cholera in West Africa: the role of food handling and high-risk foods. Am. J. Epidemiol. 131: 719-728.

Strohbehn, C.; Sneed, J.; Paez, P. and Meyer, J. (2008): Hand washing frequencies and procedures used in retail food services J. Food Prot. 71: 1641-1650.

Strohbehn, C.H.; Paez, P.; Sneed, J. and Meyer, J. (2011): Mitigating cross contamination in four retail foodservice sectors. Food Prot. Trends 31: 620-630.
Tajkarimi, M.; Ibrahim, S.A. and Fraser, A.M. (2013): Food safety challenges associated with traditional foods in Arabic speaking countries of the Middle East. Trends Food Sci. Tech. 29: 116-123.

Todd, E.C.; Greig, J.D.; Bartleson, C.A. and Michaels, B.S. (2007): Outbreaks where food workers have been implicated in the spread of foodborne disease. Part 2. Description of outbreaks by size, severity, and settings. J. Food Prot. 70: 1975-1993.

Todd, E.C.; Greig, J.D.; Bartleson, C.A. and Michaels, B.S. (2008): Outbreaks where food workers have been implicated in the spread of foodborne disease. Part 5. Sources of contamination and pathogen excretion from infected persons. J. Food Prot. 71: 2582-2595.

Todd, E.C.; Greig, J.D.; Bartleson, C.A. and Michaels, B.S. (2008): Outbreaks where food workers have been implicated in the spread of foodborne disease. Part 4. Infective doses and pathogen carriage. J. Food Prot. 71: 23392373.

Thompson, S.; de Burger, R. and Kadri, O. (2005): The Toronto food inspection and disclosure system. Brit. Food J. 107: 140-149.

Weaver, T. (1988): Theory $\mathrm{m}$ : motivating with money. Cornell Hotel and Restaurant Administration Quarterly 29: 40-45.

White, K.E.; Edmonson, L.M.; Hedberg, C.W.; Jones, D.B.; MacDonald, K.L. and Osterholm, M.T. (1989): An outbreak of giardiasis in a nursing home with evidence for multiple modes of transmission. J. Infect. Dis. 160: 298-304.

Wong, S.; Siu, V. and Tsang, N. (1999): The impact of demographic factors on Hong Kong hotel employees' choice of job-related motivators. Int. J. Contemp. Hospit. Manag. 11: 230-241.

World Health Organization. (2007): Food safety and food-borne illness. FactSheet No 237. Available at: http://www.wiredhealthresources. net/resources/NA/WHOFS_FoodSafety Foodborne Illness.pdf. Accessed April, 15, 20104.

World Health Organization/Food and Agriculture Organization. (2005): Major issues and challenges in food safety. In FAO/WHO regional meeting on food safety for the Near East. Amman, Jordan: WHO/FAO.

Worsfold, D. (2006): Eating out: consumer perceptions of food safety. Int. J. Environ. Health Res. 16: 219-29.

Worsfold, D. and Worsfold, P.M. (2007): Evaluation food hygiene inspection schemes: 'Scores on Doors' in the U.K. Int. J. Consumer Studies 31: 582-588.

Worsfold, D. and Worsfold, P.M. (2008): 'Scores on Doors': hygiene disclosure schemes for consumers. Nutri. Food Sci. 38: 22-31. 
Wright, J. and Feun, L. (1986): Food service manager certification: An evaluation of its impact. J. Environ. Health 49: 12-15.

United States Department of Agriculture. (2007): Transportation Services Branch, Transportation and Marketing Programs, Agriculture Marketing Service (USDA-AMS). Agricultural Refrigerated Truck Quarterly, 3rd Quarter, July-September. Available at: http://www.ams.usda.gov/AMSv1. 0/getfile? dDocName $=$ STELPRDC5064151\&acct =atgeninfo. Accessed May, 5, 2014.
United States Department of Agriculture. (2013): Saudi Arabia- Exporter guide. Available online at: http://gain.fas.usda.gov/Recent $\% 20$ GAIN \%20Publications/Exporter\%20Guide_Riyadh_ Saudi\%20Arabia_12-9-2013.pdf . Accessed April, 16, 2014.

United States Department of Agriculture. 2013. Saudi Arabia- Hotel restaurants institutional. Available online at: http://gain.fas. usda. gov/Recent\%20GAIN\% 20Publications/Food $\% 20$ Service $\% 20 \% \quad 20$ Hotel\%20 Restaurant \%20Institutional_Riyadh_Saudi\%20Arabia_11 -26-2013.pdf. Accessed April, 23, 2014.

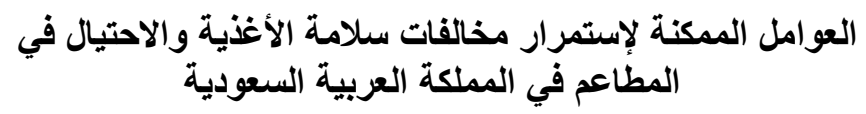

عبد الله فائز الصائغ

Email: Dr.abdulah@hotmail.com Assiut University web-site: www.aun.edu.eg

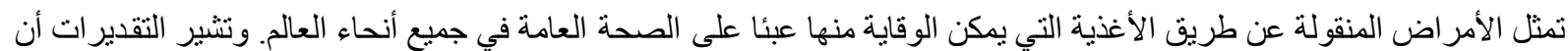

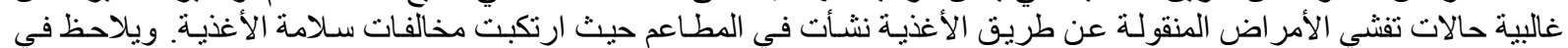

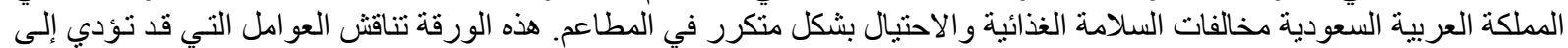

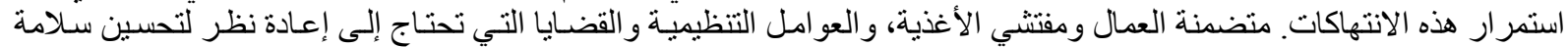
الأغذية في المطاعم وفي المملكة العربية السعودية بشكل عام. 